\title{
Germany urges universities to sharpen competition
}

Munich. The German government held high-level discussions this week with university heads and federal and Länder (state) politicians on how federal law could be changed to force universities to overcome their reputation for inefficient administration and lack of academic competitiveness.

The meeting, which was held with Jürgen Rüttgers, federal education and research minister, in Bonn, was called to discuss Rüttgers's radical hopes that Germany's overcrowded universities can be reorganized along the lines of the more competitionoriented British and US models, possibly as early as 1998 .

Rüttgers wants to solve longstanding problems such as the uneven quality of teaching and research, and excessive study

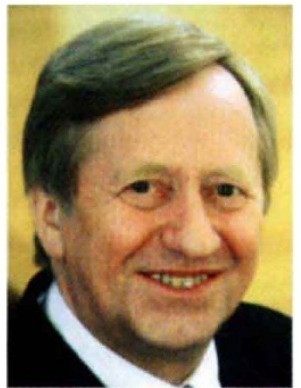

Zehetmair: striving for more flexibility. times. But to do so

he needs the support of Germany's 16 Länder, which have responsibility for all cultural affairs - including education. The federal framework law on universities, known as the Hochschulrahmengesetz (HRG), merely gives general guidelines to the Länder.

Most Länder governments agree that there is a need to reform the HRG to ensure that universities start to move with the times. But they have reacted with hostility to Rüttgers's suggestions as to how this should be done. The Länder want the HRG to be restricted in scope, giving them more autonomy. But Rüttgers doubts the willingness of all Länder to introduce the changes he considers necessary. So he wants the HRG to be more prescriptive in some areas, and to relinquish some of its democratic principles.

The federal research ministry has drawn up a long list of proposed changes to the HRG to improve universities' efficiency. Many of the points meet with general agreement - for example the proposal that universities should have full control over their budgets and their choice of academic staff, without the involvement of the Länder governments.

But two of Rüttgers's suggestions are proving particularly controversial. First, in order to widen autonomy still further, he wants universities to have the right to choose their students, rather than being obliged to take all those who apply with appropriate school certificates. Second, he wants to abolish all permanent contracts for professors.

The Länder, as well as the universities themselves, have mixed feelings about granting too much independence for universities. They fear that the changes, if implemented, could spell the end for the traditional concept of a 'German university', with its implicit recognition that degrees from all German universities are of equal value. They do not want to see Germany developing its own version of a Harvard or Cambridge university.

In any case, the prospect of being told what to do by the federal government touches a sensitive nerve. "It is unacceptable for the Länder to be told how to organize their universities," says Jürgen Zöllner, science minister of Rheinland-Pfalz.

But some of the more dynamic Länder have used their autonomy to introduce the type of changes that Rüttgers wants within the framework of the HRG. Bavaria, for example, recently introduced new rules to allow universities to offer professors shortterm contracts in the interests of flexibility. The HRG does not forbid this. Hans Meyer, president of Berlin's Humboldt University, sees this as a "Bavarian crackpot idea". But Hans Zehetmair, Bavaria's science minister, stresses that the Länder should be allowed to make up their own minds on such issues.

Some Länder would also like to be able to introduce entrance examinations for potential students, but they are barred from doing so by a clause in the HRG. Other Länder defend Germany's long tradition of equality in education, a tradition that rejects even the mildest forms of élitism. Zöllner, for example, holds fast to his argument that it is "not that universities have the right to choose their students, but rather that they have a duty to educate young people".

The most likely outcome of the current attempts at reform is that the HRG will become more restricted in scope rather than broadened in the way Rüttgers would like. No-one wants the federal framework law to be abolished completely: both the Länder and universities accept that there is a need for general principles that each university has to follow.

Earlier attempts to reform the HRG have never succeeded in breaking through the strong barrier of the principles that divide federal and Länder governments. But the pressure of Germany's financial problems is weakening this barrier and, this time around, at least some reform is likely. Nevertheless, Rüttgers's hope that consensus can be achieved before the end of the year, and reforms put into effect by the end of next year, almost certainly underestimates the strength of his opponents.

Quirin Schiermeier
Canadian researchers hope for replacement for 'best' submersible

Ottawa. Canada's ocean scientists are waiting anxiously to learn whether the government will agree to provide a replacement for what is claimed to be the world's most effective robotic research submersible, which was lost at sea during a storm last month.

The Remotely Operated Platform for Ocean Science (ROPOS) broke away from a US research ship to which it was tethered in the Juan de Fuca Strait while being battered by 15-metre waves and 140kilometre-an-hour winds.

Although ROPOS was insured, scientists are concerned that the insurance money may be used for purposes other than a replacement. Canada's federal fisheries and oceans department, which owned ROPOS, has already seen its research responsibilities reduced by budget cuts.

The submersible's insurance policy was arranged by a non-profit consortium called the Canadian Scientific Submersible Facility, formed this year to take over management of ROPOS. Initially the consortium was told by a fisheries official that the insurance money was to be used to buy other equipment. But at the end of last week the scientists learned that senior officials at the department were looking favourably at ROPOS's replacement, and a decision was expected shortly.

Kim Juniper, a biology professor at the University of Quebec at Montreal and a member of the consortium, says that the department had received more than 30 letters from the international oceanographic community supporting the replacement of ROPOS.

"If we don't replace ROPOS it will be absolutely devastating to the marine scientific community, not just in Canada but internationally," says Steve Scott, a geologist at the University of Toronto who is also a consortium member. "There would be a huge reduction in deep submergence capability in the world."

ROPOS is widely considered to be the world's best functional remotely-operated vehicle. The US vehicle Jason does not have such a successful track record. A French submersible, currently under construction, is likely to be expensive to operate, while the performance of a Japanese submersible is said to have been disappointing.

This summer ROPOS dived to almost 5,000 metres, and spent 17 hours on the seabed off the Aleutian Islands. According to Scott, failure to replace it would be a blow not only to the scientific community, but also to the government's ability to service the 25 per cent of its territory that lies underwater. 